\title{
Study on the Historical Evolution of Capital Connotation
}

\author{
Fanqiang MENG \& Baoguo DENG \\ School of Management, Zhongkai University of Agriculture and Engineering, Guangzhou, China
}

\begin{abstract}
The author uses historical analysis method on the historical evolution of capital connotation and the diversification of capital development. Through the analysis, the author discoveries: from the day concept of capital was put forward, people know about the capital form from money, physical capital, and later on the knowledge, skills and other intangible human capital, then to the social capital such as social network, moreover, scholars who do researches on cultural capital are more concerned of knowledge capital and other new forms of capital. This shows that with the development of society and economy, people on the understanding of capital is deepening and the understanding of capital form has been deepened continuously. KEYWORD: Capital connotation; Capital forms; Physical capital; Human capital; Social capital
\end{abstract}

Capital is a very important economic category in the social economy development. No matter in capitalist society or socialist society, so long as the commodity economy system implements, then the capital has the pivotal function in the production. But in the economic theory, there hasn't been a recognized conclusion about the capital connotation and essence in the academic circles yet. Different school of thought has respectively explanation regarding the capital category.

\section{MERCANTILISTS' UNDERSTANDING OF CAPITAL CONNOTATION}

The issue of capital can be dated back to the lending relationship at first. Mainly in the form of currency, capital was initially referred to Principal of the loan, responding to interests. By the late medieval period, with the emergence and development of the capitalist way of production, commercial capital played a more and more important role in the social economic life. People naturally focused on exploring the capital configuration in terms of the investigation of the capital, followed by the emergency of Mercantilist School. Mercantilism inherited the idea that capital equaled to currency in the early days, so it was considered that currency consisted of the single source and form of fortune. Distinct from the investigation of the capital in the earlier society, Mercantilists studied the appreciation of the monetary capital from a perspective of the commodity circulation. Mun, Papen and North came up with the thought and concepts of inventory successively, stating that it was the role of existence in the trade that led to surplus. In fact, inventory here meant the commodity capital in circulation. Thus we can see that Mercantilists never limited to the value-added capability of the commodity capital any more as for the investigation of the capital, but transferring their focus to value-added capability of monetary capital. To some extent, they separated money-form capital with commodity capital purchased by money and to be offered for sell while widening their visions. Limited to the field of circulation, Mercantilists still didn't touch on capital in the production process. So, their cognition for capital was still plain or not full-fledged enough as a whole.

\section{PHYSIOCRATS' UNDERSTANDING OF CAPITAL CONNOTATION}

In late 17 century, Mercantilism declined gradually and French Physiocrats rose. Different with mercantilism, Physiocrats studied capital mainly from the view of production. Quesnay, the founder and representatives of the Physiocrats, argued that Agriculture is the only production sector and the only source of wealth in society. Only agricultural production can increase social wealth. Therefore, He believed that only investment in agricultural production is real capital. Capital invested in other areas is not real capital. Thus, different from Mercantilist which put capital equal monetary 
capital, Quesnay put capital equal productive capital and mixed capital and the production forms of capital. He only saw the production forms of capital, but did not see the Circulation form of capital. What's more, neglecting the existence of other forms of productive capital, Quesnay restricted the productive capital is agricultural capital.

Turgot, another representative of Physiocracy, makes a deeper analysis of capital than Quesnay. Turgot thinks that capital is the accumulation of the moving value. And any products which are not consumed and thus accumulated are "movable wealth ". As it is not consumed as life material, can be disposed by its owner and obtain some revenue, it became the capital. It can be seen from the definition of capital by Turgot that the capital he inspected not only including production material, but also including currency and reserves, etc form of consumer goods. So, he not only sees the production form of capital, and also the goods form and monetary form of capital.

\section{DEFINITION OF CAPITAL CATEGORY BY CLASSICAL ECONOMISTS}

With the completion of the industrial revolution and the establishment of the capitalist mode of production, the classical school of economics appeared onto the arena of history, so that Western capital theory went into the classical period of development. Capitalist mode of production is characterized by the huge manufacturing and using capital goods in the production process, implementing the most extensive roundabout production. This objective condition makes the classical school examine capital issues systematically from the production process.

British economist Adam Smith thinks that capital is accumulation or storage used to continue the production, that is the means of production. Storage products appear with the development of division of labor and exchange, of which capitalists are those who own the accumulation of storage products, when they take out some of them to get some income, then capital emerges. It can be seen that Smith equates capital to means of production, which is different Quesnay's capital theory is that production capital Smith referred to is not limited to the scope of agricultural capital. Ricardo has a broader definition of capital, who thinks not only the capital goods is capital, and the means of production also belongs to the scope of the capital. He said, "Even in the early state as Adam Smith said, although the capital may be accumulated by the hunters themselves, he always have some capital to hunt birds. Without a weapon, he cannot hunt beaver or deer."
Thus, from the late Middle Ages to the 18th century classical economics period, although all schools have different elaboration of capital, there is one thing in common that equates capital to specific forms of material. No matter mercantile capital is monetary, or physiocracy capital is agricultural capital, or neoclassical capital is means of production, they only do the research into the surface of capital, while neglecting the deeper meaning hidden behind the materialized form of capital, and later Marx made an in-depth and comprehensive analysis of the nature of content of capital.

\section{THE PROFOUND ANALYSIS OF CAPITAL}

Critically inheriting the capital theory of classical economics, Marx establishes his own capital theory which holds a significant position in the whole economic theories. Specifically speaking, Marx reveals the connotation from the perspectives of increment and sociality.

On the one hand, Marx inherits some reasonable thought of western economics which reveals the general property of capital, namely, the increment of value. Marx holds that the means of production is the materialized form and carrier of capital; as the embodiment of subjects, capital is materialized by means of equipment, plant and raw materials and other physical forms. Meanwhile, capital is able to produce the surplus value; and the increment of value is the most general property of capital. Marx demonstrates this general property by analyzing the commendation of labor force. Through the form of currency, capital is used to buy required labor force and instruments and produce commodity used for exchange; by means of exchange capital increases in the form of currency. And the added value is the increment of value of capital.

On the other hand, though Marx proposes that the means of production is the materialized form of capital, he opposes the western economists' thought of regarding capital and production means as the same thing. In his point of view, the essence of capital is not object. "Capital is also a kind of social production relations. This is the bourgeois' production relations and the bourgeois society's production relations". In the third value of Das Kapital gives a detailed description "Capital is not object. It is a kind of particular and social production relations embodied in certain social history configuration. It is manifested in an object and attaches distinctive social attribute to the object. Capital is not the accumulation of materials and produced materials. "This follows that in Marx's view the capital is beyond substantial form. What he sees is the hidden social relation behind the capital substantial form. He points out those things like the 
means of production only form under certain social relations, without it there is no longer capital. Therefore, the capital is not created out of thin air but under a certain social condition.

According to the Marx's discussion about capital: on the one hand, Marx inherited the rational ideas of Western Economics that proliferation is a general property of capital. Capital can produce the surplus value .It also thoroughly explains the mechanism and process about how the capital achieve proliferation. At the same time, Marx also believes that capital is usually manifested in the form of a certain material. Machinery, plant, raw materials and other capital goods are all the specific materials in the form of capital, which also has similarities with Western economics. But on the other hand, Marx also criticized the Western economists who have the idea that capital and production, money and other material in the form of capital is equivalent. $\mathrm{He}$ believes that the nature of capital is not goods, but social relations between people which hide behind materials. At this point, Marx truely exceeds the Western economists.

\section{THEODORE SCHULTZ EXPANDED THE CONNOTATION OF THE CAPITAL}

From the discussion above we could find that the capital analyzed by Marx and the former economist was mostly referred to the tangible physical capital in terms of money and production material. With the development of modern society, the factors such as information, knowledge, education and so on, were playing more important roles in the development of economic .And this importance challenged the traditional idea. The capital was limited to the tangible physical in the traditional definition. In this case, the connotation expansion of the capital became inevitable.

The famous American economist Schultz put forward the concept of human capital for the first time. He thought that the natural resources, land and material capital were not enough to explain the productivity. Human was the vital reason for the social progress. For one country, the huger of the human capital stock, the higher of the human resources quality, and so does the domestic output per person or the labor productivity. Thus he thought that the traditional theory of capital emphasized the role of physical capital and ignored the human capital in the role of the development of modern economy. Therefore, the traditional theory of capital lacked a complete capital concept. In the article "the theory of human capital investment" Schultz pointed out the comprehensive capital concept should include two aspects things and people, that is, human capital and material capital. The main form of physical capital was material products; and the main form of human capital was the laborer. Human capital was formed by investment and made up with knowledge, skill and strength. In other words, human capital was the capital that reflected in the workers by the quality and quantity. Schultz thought the key of the human capital investment was education. He analyzed the relationship between the U.S. economic growth and education from 1929 to 1957.Then he thought the level of education spending was not only the main factor to decide the human capital quality but also an important factor to the national income and economic growth. Later, Becker and Romer took a more deep research on this issue.

The person's knowledge and ability can be used to generate more profit. And this characteristic made them called the capital. They could be put into production as the production factors and could bring the corresponding income. The concept of human capital expanded the connotation of capital that is people's knowledge and ability also could be regarded as capital. In this case, everyone could increase their own human capital by increasing their ability, so as to achieve greater returns. Thanks to the concept of the human capital, the connotation of capital existed without the material entity for the first time, and this helped capital get rid of the specific physical form. What's more; it laid the etymology foundation for the concept of the social capital.

\section{PROPOSAL OF SOCIAL CAPITAL}

The concept of "social capital" first appeared in the study of economics actually, but it is not the sense of that in modern times. For example, early in the 19th century, the Austrian scholar Bohm-Bawerk proposed the concept of "social capital", which mainly referred to the means and products of wealth obtained from socio-economic aspect. Marx has also mentioned the concept of "social capital" in Capital, in which the social capital he referred to actually meant social total capital, "the aggregation of share capital by all individual capitalists". Therefore, concept of social capital in the early days has different meaning with "social capital" which reflects social relations between people subsequently understood by sociologists.

In 1980, French sociologist Bourdieu published an article entitled with "Social Capital Essay" in the magazine of Social Science Research, formally proposing the concept of "social capital". He emphasized that social capital is a group identity, defining social capital as: "Social capital is the sum of actual and potential resources owned by social network members or groups, which are commonly possessed by a specific group members and provide 
shared resource support for each member of the group".

From Bourdieu's concept of social capital, it can be seen that social capital is a collection of resources, which can be occupied and used by actors, while the number of possession of social capital depends on the size of the network links he can use effectively as well as on the umber of social capital(economic, cultural, symbolic) owned by everyone he has contact with how much the amount of capital. It can be said that Bourdieu was the first one pioneering in the social capital research. He made a relatively comprehensive and general definition of social capital at the earliest, proposed a series of theoretical propositions of social capital, and thus formed a research paradigm on social capital. He also brought social capital into his general capital theory, carefully studying the relation of social capital and other forms of capital. After Bourdieu's pioneering research into social capital, it has gradually drawn people's attention and attracted more people to make an exploration.

Putting forward the concept of social capital provides a new perspective to economists, sociologists, management scientists and political scientists in explaining the economic growth, business growth and so forth. At the same time, it also makes the capital expand for the third time, which illustrates that capital can't only not exist attached to material objects, or can't also attached to the man himself, which gives the content of the capital a broader and abstract expansion. As a result of fact, it will be the synonym that can bring all the resources as the value of proliferation.

\section{SUMMARY AND OUTLOOK}

Thus, through the historical view of observing "capital", we can see that with the times gradually expanding, the meaning of capital changes. People started to pay attention from the physical capital (money, production, etc.), to the value of human capital afterwards (knowledge, skills, etc.), then later, the attention of social capital (social networks), which reflects the content of people's understanding towards capital are increasingly getting more plentiful and more profound.

It is noteworthy that the above all we are talking about is the main line of content development of the capital, and not all forms of capital are included. Some scholars have also proposed a cultural capital, intellectual capital and other related concepts as well. we can see, the content of capital with the development of society is continually expanding, increasingly diverse forms of capital are showing up meanwhile. Of course, some scholars would question the new concept of capital, for example, the famous American economist Robert Solow questioned on the "social capital" concept. In his view, to explore social capital and economic interaction between the modes of operation is a thankless job. Only human capital and physical capital is sufficient in contributing to economic development, there is no need to join the social capital. Because the trust, cooperation and willingness and ability of coordination mentioned in social capital can be classified as human capital. Although there is controversy in academic circles, but the meaning of capital expansion and diversification of forms of capital is a big trend. It is foreseeable that in future studies on the capital, as it deepens the understanding of capital, the meaning of capital will continue to be deepened and expanded, and new forms of capital will continue to emerge.

\section{ACKNOWLEDGEMENT}

This research was financially supported by the Social Science Foundation of Guangdong (GD12CGL02).

\section{REFERENCES}

[1] Durlauf, S.N. \& Blume, L.E. 2008. The New Palgrave: A Dictionary of Economics. London: Palgrave Macmillan.

[2] Ricardo, D. 1988. On the Principles of Political Economy and Taxation. Beijing: Commercial Press.

[3] Marx, K. 1975. Das Kapital. Beijing: People's Publishing House.

[4] Schultz, T.W. 1961. Investment in Human Capital. The American Economic Review 51(1):1-17.

[5] Becker, G.S. 1985. Human Capital, Effort, and the Sexual Division of Labor. Journal of Labor Economic 3(1):S33S58.

[6] Romer, P.M. 1989. Human capital and growth: theory and evidence. National Bureau of Economic Research, Working Paper 3173:1-41.

[7] Jones, C.I. \& Romer, P.M. 2010.The New Kaldor Facts: Ideas, Institutions, Population, and Human Capital. American Economic Journal: Macroeconomics 2(1):224245 ,

[8] Bourdieu, P. 1980. Le capital social. Actes de la recherche en sciences socials 31: 2-3.

[9] Bourdieu, P. 1986.The Forms of Capital. Handbook of Theory and Research for the Sociology of Education. New York: Greenwood Press.

[10] Bourdieu, P.1997.Le Champ Economique. Actes de la recherche en sciences socials 119: 48-66.

[11] Solow, R.M. 2000. Notes on social capital and economic performance. Social capital: A multifaceted perspective. Washington, DC: World Bank. 